Office: 'T. A. R. Choate (forester, grade 1, Kenya), assistant conservator of forests, Kenya; A. J. L. Mitchell (assistant conservator of forests, Western Region of Nigeria), senior assistant conservator of forests, Western Region of Nigeria ; J. K. Ross (senior assistant conservator of forests, Western Region of Nigeria), conservator of forests, Western Region of Nigeria; R. B. McConnell (director of Geological Survey, Bechuanaland), director of the Geological Survey, British Guiana; J. C. Alley (veterinary officer, Tanganyika), veterinary officer, Aden; D. H. Mackenzie, temporary field geologist, Sierra Leone; A. D. H. Bivar, assistant surveyor, antiquities, Federation of Nigeria; Miss M. M. Bools, assistant bacteriologist, Barbados; K. M. Cripps; meteorologist, Cyprus; D. Kay, plant pathologist, West Africa Cocoa Research Institute, Gold Coast, D. A. Lury, statistician, East Africa High Commission; A. Pinkerton, soil surveyor, Kenya; $H$. Roberts, entomologist, West African Timber Borer Research Unit, Gold Coast ; C. T. Stratton, statistician, Hong Kong; J. P. Tunstall, senior scientific officer, Nyasaland.

\section{Postgraduate Scholarships in Agriculture}

Tre Ministry of Agriculture, Fisheries and Food and the Department of Agriculture for Scotland propose to award, for the academic year beginning October 1, 1957, a number of postgraduate scholarships in agricultural economics, the various branches of husbandry, farm management, statistics, agricultural and dairy engineering, rural estate management and land economics. The closing date for receipt of completed application forms is March 31. Further particulars and forms of application can be obtained from the Secretary, Ministry of Agriculture, Fisheries and Food, Room 286, Great Westminster House, Horseferry Road, London, S.W.1, or the Secretary, Department of Agriculture for Scotland, St. Andrew's House, Edinburgh 1.

\section{Announcements}

THE United Kingdom Atomic Energy Authority will open an office at Dodoma, Tanganyika, in April. This office will give technical advice to prospectors on the search for uranium ore in East Africa. It will include a laboratory equipped for sample assaying. The Authority has already established a similar office in Salisbury to service the Federation of Rhodesia and Nyaraland

Arrangements have been made for the Iron and Steel Institute and the Institute of Metals to become members of the British Nuclear Energy Conference, and for each Institute to be represented on the Board of the Conference by three members. The purpose of the British Nuclear Energy Conference is to coordinate the activities of the constituent members in the field of nuclear energy by holding meetings and publishing a Journal. The original constituent members were the Institution of Civil Engineers, the Institution of Mechanical Engineors, the Institution of Electrical Engineers, the Institute of Physics and the Institution of Chemical Enginecrs.

Tre I'rustees of the Ramsay Memorial Fellowships Trust will consider in June applications for two Fellowships for advanced students of chemistry. One of the Fellowships will be limited to candidates educated in Glasgow, who can apply to be considered for either Fellowship. The value of each Fellowship, which will normally be tenable for two years, will be
$£ 600$ per annum, to which may be added a grant for expenses of research not exceeding $£ 100$ per annum. Full particulars can be obtained from the Joint Honorary Secretaries, Ramsay Memorial Fellowships 'Trust, University College London, Gower Street, W.C.1. Completed application forms must be received not later than April 18.

THE annual Conference of the Institute of Metal Finishing, in which is incorporated the Electrodepositors' Technical Society, is to be held at the Grand Hotel, Brighton, during April 9-13. Further details may be obtained from the Conference Secre. tary, Institute of Metal Finishing, 32 Great Ormond Street, London, W.C.1.

A JOINT symposium of the Koninklijk Instituut van Ingenieurs, the Koninklijke Nederlandse Chemische Vereniging, the Society of Chemical Industry and the Institution of Chemical Engineers is to be held at Church House, Westminster, on May 28 and 29, on the "Scaling-up of Chemical Plant and Processes". Members of the sponsoring bodies can obtain further details from their respective Secretaries; others should write to the General Seeretary, Institution of Chemical Engineers, 16 Belgrave Square, London, S.W.1.

ThE Scottish Group of the Nutrition Society is holding a symposium on "Clean Food" in Aberdeen on April 20. Papers to be read deal with the bacteriology and public health aspects of food poisoning, the inspection of food, protection of food at home and by catering concerns, some clinical consequences of food poisoning, and the spoilage of fish. Further particulars can be obtained from Dr. J. Davidson, Rowett Research Institute, Bucksburn, Aberdeenshire.

THE Arbeitsgemeinschaft Deutsche KunststoffIndustrie, in association with Kunststofferzeugende Industrie und verwandte Gebiete e.V. and Gesemtverband kunststoffverarbeitende Industrie $\Theta . V$., together with the German Physical Society, the German Chemical Society, the Deutsche Normenausschuss and the Verein Deutscher Ingenieure, are to organize a Plastics Conference at Bad Pyrmont during April 10-11. Further information can be obtained from the Conference Organizing Committee, Frankfurt am Main 1, Karlstrasse 21.

A symposrum organized by the Division of Plastics and High Polymers of the International Union of Pure and Applied Chemistry, on the subject of the relationship between the physical chemistry and the testing (with special reference to standardization) of elastomers, fibres and plastomers, based on their structure, is to be held in Paris during July 25-26. Further details can be obtained from the secretary, Prof. P. Dubois, 292 rue St.-Martin, Paris 3.

THe Cornell Summer Laboratory Course in Techniques and Applications of the Electron Microscope will be given during June 17-29 by the laboratory of electron microscopy in the Department of Engineering Physics, Cornell University. This course, which is intended primarily for workers in the fields of physics, chemiatry and metallurgy, is under the direction of Prof. B. M. Siegel, and all inquiries should be addressed to him at the Department of Engineering Physics, Cornell University, Ithaca, New York.

Messrs. BX Plastics, Lidd., point out that 'Styra. foil', mentioned in Nature of February 9, p. 322, is not a form of 'Cellophane', but an orientated polystyrene film. 